\title{
RECONHECIMENTO DE PATERNIDADE POR TESTAMENTO
}

\author{
Ana Lúcia Alves Feliciani ${ }^{1}$
}

\section{INTRODUÇÃO}

$\mathrm{O}$ ato de testar, em sua historicidade, remonta à antiga Roma, ${ }^{2}$ onde era atribuída a especial importância à sucessão testamentária em detrimento da sucessão $a b$ intestato, ${ }^{3}$ e o elemen- to essencial era "a instituição de herdeiro (institutio heredis): o testador deveria designar expressamente uma ou mais pessoas chamadas a receber $o$ seu patrimônio, ou seja, o conjunto de seus bens"4. A sucessão testamentária quase desaparece na Idade Média $^{5}$ e

1 Doutoranda em Direito (UFRGS). Mestre em Direito (UFRGS). Especialista em Direito Civil Aplicado (UFRGS). Graduada em Direito pela Pontifícia Universidade Católica do Rio Grande do Sul (PUCRS/Uruguaiana). Advogada. Assessora Jurídica da Procuradoria-Geral do Estado do Rio Grande do Sul. Membro Pleno da ASADIP.

2 Acerca da sucessão testamentária, Fustel de Coulanges anota que, primitivamente o testamento não era conhecido, tendo em conta que a transmissão da propriedade por morte era intimamente relacionada às crenças religiosas. $\mathrm{O}$ homem adquiria a propriedade pelo culto doméstico e não pelo trabalho, e isso independia da vontade do morto, porque aquela não lhe pertencia, mas à sua família. Era desconhecido no antigo direito hindu; proibido no direito ateniense até Sólon de maneira absoluta, salvo para que aqueles que não deixassem filhos; em Esparta, é autorizado após a guerra do Poloponeso. In: Cidade Antiga. São Paulo: Martins Fontes, 2000, p. 69-85.

3 GILISSEN, John. Introdução Histórica do Direito. Tradução de A. M. Hespanha e L.M. Macaísta Malheiros. Fundação Calouste Gulbenkian. Lisboa. 2. ed. 1995, p. 690.

4 GILISSEN, John. Idem.

5 GILISSEN, John. Idem. 
renasce com o Direito Canônico, que incentiva a realização do testamento em razão de vantagens advindas às instituições eclesiásticas, que chegaram a afirmar que "o que morre intestado, sem ter feito pelo menos um legado pio, fica em pecado."

Persistiu a sucessão testamentária nos séculos XIX e XX. Da Revolução Francesa o Code civil, embora a influência do Direito Romano, adotou o primado da liberdade absoluta de expressão da vontade do testador. ${ }^{7}$ O Código Civil francês influenciou vários países da Europa e também outros fora do continente europeu, dentre os quais o Brasil.

A evolução legislativa brasileira relativa à sucessão testamentária, igualmente marcada pela tradição romanista, passa pelas Ordenações do Reino - Ordenações Afonsinas (1.446), Ordenações Manuelinas (1.521) e Ordenações Filipinas (1.603), bem como pela Consolidação das Leis Civis, de Augusto Teixeira de Freitas, de $1.859 .{ }^{8} \mathrm{Na}$ codificação de $1916,{ }^{9}$ a disciplina da sucessão testamentária veio expressa em conformidade com valores sociais e culturais de sua época.

Mas é essencialmente com o advento da Constituição Federal de 1988 que o ato de testar ganha uma nova dimensão, correlacionando-se com os direitos fundamentais, dentre os quais o direito fundamental de herança, expresso primeira vez como garantia institucional, ${ }^{10}$ pois é a pessoa humana que passa a ser o centro do ordenamento jurídico brasileiro, e é a sua dignidade que se quer proteger. Ao legislador ordinário ${ }^{11}$, cabe, nesse mister, dar concretude ao mandamento constitucional, indicando os modos e as condições do ato de testar, ao tempo em que limita a autonomia da vontade do testador e possibilita disposições de cunho não apenas patrimoniais, mas existenciais, retoman-

6 GILISSEN, John. Idem.

7 GILISSEN, John. Idem, p. 694.

8 Seguiram-se a Consolidação das Leis Civil, de Augusto Teixeira de Freitas, os anteprojetos, de Nabuco de Araújo (1.872), Felício dos Santos (1.881), Coelho Rodrigues (1.893) e Clóvis Beviláqua (1.889).

9 Nesse sentido, e para estudo detalhado da evolução histórica do Direito Sucessório, remetemos o leitor para a obra de Euclides de Oliveira. Direito de Herança: a nova ordem da sucessão. São Paulo: Saraiva, 2005, p. 15-34.

10 Martins-Costa, Judith. Comentário ao art. 5., inciso XXX. In: CANOTILHO, J. J. Gomes; MENDES, Gilmar F.; SARLET, Ingo W.; STRECK, Lenio L. (Coords.) Comentários à Constituição do Brasil. São Paulo: Saraiva/Almedina, 2013, p. 337-342.

11 Ibidem. Na atualidade, o Código Civil de 2002. 
do-se a disciplina dos correspondentes direitos de personalidade.

Em uma leitura sistemática, o ato de testar alcança diversas áreas do Direito. Exemplificativamente, no âmbito do Direito de Família, a proteção desta vem evidenciada pela transmissão do patrimônio como um dos aspectos da solidariedade familiar, ${ }^{12}$ providência em que a deixa testamentária pode favorecer não apenas a família nuclear ${ }^{13}$ ou a extensa,,${ }^{14}$ mas outras pessoas indicadas pelo testador. Além disso, o reconhecimento de paternidade por testamento poderá modificar o estado de família do perfilhante e do perfilhado. ${ }^{14}$ Patrimônio e existência humana destacam-se na promoção desse princípio.

No Direito Tributário, considerando-se como destinatários do direito de herança os cidadãos e o Estado, ${ }^{15}$ tem-se a incidência do Imposto de

12 Ibidem.

13 Família nuclear é aquela composta pelos pais ou um deles e por seus descendentes. Ilustrando hipótese em que a viúva é agraciada pelo testamento, já decidiu o TJRS: AGRAVO DE INSTRUMENTO. INVESTIGAÇÃO DE PATERNIDADE POST MORTEM. EXISTÊNCIA DE INTERESSE POR PARTE DA VIÚVA, AGRACIADA EM TESTAMENTO ELABORADO PELO EXTINTO. ART. 1.793 DO CCB. No caso, tendo sido a viúva contemplada em testamento deixado pelo falecido investigado, possui interesse no deslinde da ação de investigação de paternidade post mortem, em que se noticia a existência de pretensão de direitos patrimoniais, ante o teor do art. 1.793 do CCB (rompimento do testamento). AGRAVO DE INSTRUMENTO DESPROVIDO. (Agravo de Instrumento $\mathrm{N}^{\circ}$ 70053379772, Oitava Câmara Cível, Tribunal de Justiça do RS, Relator: Ricardo Moreira Lins Pastl, Julgado em: 11/04/2013).

14 A Lei n. 12.010/2009, a nova Lei da Adoção, positivou o conceito de família extensa ou ampliada, como "aquela que se estende para além da unidade pais e filhos ou da unidade do casal, formada por parentes próximos com os quais a criança ou adolescente convive e mantém vínculos de afinidade e afetividade", ao tempo em que conceituou implicitamente a família nuclear, como a composta pela "unidade pais e filhos ou da unidade do casal".

14 Mas não se pode olvidar que, em contrapartida, a investigação de paternidade poderá ter como efeito o rompimento daquele, como recentemente decidiu o TJRS, cujo acórdão restou assim ementado: TESTAMENTO PÚBLICO. ROMPIMENTO. PROVA. 1. Sendo o testamento um negócio jurídico solene, deve observar todas as formalidades previstas na lei. 2. Verifica-se o rompimento do testamento, quando o testador declara não possuir descendentes e, após o seu óbito, é reconhecida a sua paternidade em sede de ação investigatória. Inteligência do art. 1.973 do Código Civil. 3. É roto também o testamento quando contém declaração falsa. Recurso desprovido. (Apelação Cível No 70045211042, Sétima Câmara Cível, Tribunal de Justiça do RS, Relator: Sérgio Fernando de Vasconcellos Chaves, Julgado em: 24/10/2012).

15 Martins-Costa, Judith. Comentário ao art. 5., inciso XXX. In: CANOTILHO, J. J. Gomes; MENDES, Gilmar F.; SARLET, Ingo W.; STRECK, Lenio L. (Coords.) Co- 
Transmissão Causa Mortis e Doação (ITCD). ${ }^{16} \mathrm{O}$ exame da destinação do quantum arrecadado e da identificação do agente passivo da obrigação tributária podem depender do testamento. $^{17}$

No Direito Penal, a ausência da observância das rígidas formalidades que envolvem o ato de testar, bem como da capacidade testamentária ativa pode resultar em responsabilização criminal, como já enfrentou o Tribunal de Justiça gaúcho. ${ }^{18}$ Também não se permite ao testador fraudar a lei ou a legítima, por meio de disposições ideologicamente falsas.

No Direito Econômico e Empresarial, ao permitir a transmissão

mentários à Constituição do Brasil. São Paulo: Saraiva/Almedina, 2013, p. 337-342. Acerca do tema, anota a autora que, quanto aos destinatários do direito constitucional de herança, "trata-se de direito de defesa, pois ao assegurar a garantia do direito de herança e, inclusive revesti-la com a fixidez de cláusula pétrea (art. 60, IV), a Constituição cria uma intangibilidade à herança demarcada pela vedação do Estado de abolir o instituto ou restringir excessivamente o direito sucessório, realizando, por exemplo, o confisco dos bens deixados por sucessão em virtude de morte. Positivamente, têm os cidadãos o direito de exigir omissões dos poderes públicos, de forma a evitar agressões lesivas à garantia por parte dos mesmos".

16 AGRAVO DE INSTRUMENTO. INVENTÁRIO. IMPOSTO DE TRANSMISSÃO CAUSA MORTIS E DOAÇÕES - ITCD -. TESTAMENTO. ALÍQUOTA. Em se tratando de sucessão testamentária, aplica-se ao ITCD a alíquota de $3 \%$ prevista no art. 19 da Lei Estadual n. 8.821/8919. Apelação provida. (Agravo de Instrumento $\mathrm{N}^{\circ}$ 70056755853, Sétima Câmara Cível, Tribunal de Justiça do RS, Relator: Jorge Luís Dall'Agnol, Julgado em: 18/12/2013).

17 AGRAVO DE INSTRUMENTO. DILIGÊNCIA. Ante a dúvida a respeito do objeto do legado que beneficiou dois filhos e um neto do falecido, necessário se faz a presença do testamento nos autos do agravo, a fim de que se esclareça de quem é a responsabilidade pelo pagamento do tributo exigido pelo fisco, uma vez que dois filhos legatários formavam sociedade com o pai em uma empresa comercial. (Agravo de Instrumento No 70005659511, Oitava Câmara Cível, Tribunal de Justiça do RS, Relator: Antônio Carlos Stangler Pereira, Julgado em: 26/06/2003).

18 APELAÇÃO. FALSO IDEOLÓGICO. TESTAMENTO. AUSÊNCIA DE DOLO OU DE SUA COMPROVAÇÃO. Auxiliar de tabelião que, na lavratura de testamento, sem alteração substancial do ato, deixa de cumprir determinadas formalidades legais, sem maior relevância observada a finalidade do mesmo, não incorre nas penas do falso ideológico. Ausência de prova de dolo. Apelo improvido. (Apelação Crime $\mathrm{N}^{\circ}$ 70003984226, Oitava Câmara Criminal, Tribunal de Justiça do RS, Relator: Tupinambá Pinto de Azevedo, Julgado em: 18/02/2004).

19 AGRAVO DE INSTRUMENTO. INVENTÁRIO. SUSPENSÃO ATÉ ULTIMAÇÃO DO TESTAMENTO. CABIMENTO DE NOMEAÇÃO DE GERENTES PARA 
da herança em conformidade com a vontade do testador, modifica-se a titularidade dos bens transmitidos, modificando, por conseguinte, a situação do agente econômico, ${ }^{19}$ ou seja, quem pratica atos jurídicos guardando em si o Poder Econômico, o qual pode ser Público ou Privado, bem assim, quem sofre seus efeitos, o consumidor.

No biodireito, uma nova modalidade de testamento, o vital ${ }^{20}$, foi recentemente objeto de exame pelo Tribunal de Justiça gaúcho. ${ }^{21}$ É o testador determinando, em vida, as condições de sua morte, no mais pleno exercício da autonomia da vontade individual, na promoção de uma morte digna.

Dada a atualidade e importância do tema, o presente estudo busca uma revisitação ao direito sucessório, especialmente à sucessão testamentária, analisando precipuamente o conteúdo existencial das disposições testamentárias, dentre as quais a perfilhação, ato que envolve direitos de personali-

ADMINISTRAÇÃO DE EMPRESA, NO INTERESSE DE TODOS OS HERDEIROS. DERAM PARCIAL PROVIMENTO. (Agravo de Instrumento No 70000124115, Sétima Câmara Cível, Tribunal de Justiça do RS, Relator: Luiz Felipe Brasil Santos, Julgado em: 15/09/1999).

$20 \mathrm{O}$ testamento vital não será objeto de exame do presente estudo, embora a importância desse novo meio de proteção à dignidade da pessoa humana, que pode viabilizar uma morte digna.

21 APELAÇÃO CÍVEL. ASSISTÊNCIA À SAÚDE. BIODIREITO. ORTOTANÁSIA. TESTAMENTO VITAL. 1. Se o paciente, com o pé esquerdo necrosado, se nega à amputação, preferindo, conforme laudo psicológico, morrer para "aliviar o sofrimento"; e, conforme laudo psiquiátrico, se encontra em pleno gozo das faculdades mentais, o Estado não pode invadir seu corpo e realizar a cirurgia mutilatória contra a sua vontade, mesmo que seja pelo motivo nobre de salvar sua vida. 2. O caso se insere no denominado biodireito, na dimensão da ortotanásia, que vem a ser a morte no seu devido tempo, sem prolongar a vida por meios artificiais, ou além do que seria o processo natural. 3. O direito à vida garantido no art. $5^{\circ}$, caput, deve ser combinado com o princípio da dignidade da pessoa, previsto no art. $2^{\circ}$, III, ambos da CF, isto é, vida com dignidade ou razoável qualidade. A Constituição institui o direito à vida, não o dever à vida, razão pela qual não se admite que o paciente seja obrigado a se submeter a tratamento ou cirurgia, máxime quando mutilatória. Ademais, na esfera infraconstitucional, o fato de o art. 15 do CC proibir tratamento médico ou intervenção cirúrgica quando há risco de vida, não quer dizer que, não havendo risco, ou mesmo quando para salvar a vida, a pessoa pode ser constrangida a tal. 4. Nas circunstâncias, a fim de preservar o médico de eventual acusação de terceiros, tem-se que o paciente, pelo quanto consta nos autos, fez o denominado testamento vital, que figura na Resolução $\mathrm{n}^{\circ}$ 1.995/2012, do Conselho Federal de Medicina. 5. Apelação desprovida. (Apelação Cível No 70054988266, Primeira Câmara Cível, Tribunal de Justiça do RS, Relator: Irineu Mariani, Julgado em: 20/11/2013). 
dade do testador e do perfilhado. Para tanto, o estudo será divido em três partes. A primeira, estará voltada para o exame da sucessão testamentária, apontando seus requisitos essenciais e sua validade, tal como dispostos no Código Civil em vigor, buscando analisar os conteúdos patrimonial e existencial da vontade do testador. No segundo ponto, analisar-se-á o reconhecimento de paternidade pela via testamentária, como disposição de cunho existencial. Na última parte, o estudo buscará examinar os direitos de personalidade e o direito à filiação.

\section{CONTEÚdOS PATRIMONIAL E EXISTENCIAL DO TESTAMENTO}

A morte determina a abertura da sucessão, ${ }^{22}$ e a herança transmite-se, desde logo, aos herdeiros legítimos ou testamentários. ${ }^{23}$ A sucessão dá-se por lei, ou por disposição de últi- ma vontade,${ }^{24}$ sendo que, na ausência desta, a partilha dos bens segue o critério legal, convocando-se a suceder os familiares mais próximos, em conformidade com a ordem de vocação hereditária. $^{25}$

Mas é a sucessão testamentária que guarda não apenas sentido econômico ante a possibilidade de transmissão patrimonial em conformidade com a vontade do morto, mas também aspectos sociais e morais, ante a viabilização tanto da "distribuição das riquezas fora do círculo restrito dos parentes, às vezes não bastante necessitados quanto um estranho contemplado pelo autor da herança. ${ }^{26} \mathrm{E}$, para além disso, possibilita a satisfação do querer em sua face puramente existencial.

O Código Civil de 2002 proporciona essas possibilidades ao testador, regulando a sucessão testamentária nos artigos 1.857 a 1.990 , somando 133 dispositivos, revelando ademais, a importância do testamento no direito brasileiro. ${ }^{27}$ É o prestígio da vonta-

22 RIZZARDO, Arnaldo. Direito das Sucessões. 4. ed. Rio de Janeiro: Forense, 2008, p. 22.

23 Art. 1.784, Código Civil de 2002.

24 Art. 1.786, Código Civil de 2002.

25 NADER, Paulo. Direito da Sucessões. V. 6. 2. ed. Rio de Janeiro: Forense, p. 194. 26 RIZZARDO, Arnaldo. Ob. cit., p. 227.

27 Eduardo de Oliveira Leite refere, no entanto, que "a regra, no Brasil, desde a Colônia até à República, era a utilização do testamento e a exceção era a morte ab intestato. 
de do testador, consoante sua autonomia pessoal, capaz de "modificar ou inverter uma ordem de atribuição de bens estabelecidos pela própria lei, ${ }^{28}$ substituindo-se, total ou parcialmente, a sucessão legítima, pela voluntária". ${ }^{29}$

E é por essa razão que o testamento tem rigorosa disciplina legal. Ao tempo em que permite que seu conteúdo se distancie da sucessão legítima e albergue disposições existenciais, obedece criteriosamente os parâmetros formais impostos pela lei. Ato jurídico ${ }^{30}$ que é, veicula a declaração de vontade do testador na modalidade de negócio jurídico unilateral, personalíssimo, formal e solene, gratuito, revogável e mortis causa.

É negócio jurídico unilateral, porque o testamento se forma mediante declaração de vontade do testador, tendo efeitos previsíveis pelo ordenamento jurídico, o que confirma o caráter unilateral do ato; é ato personalíssimo, não podendo ser praticado por duas ou mais pessoas e nem por terceiros ou por procuração, mas apenas o disponente pode dizer de sua vontade para depois de sua morte; é gratuito porque é defesa à imposição de contraprestação ao ato de testar, ainda que haja instituição de legado com encargo; a formalidade e solenidade são garantias legais a fim de permitir o cumprimento da real vontade do testador, afastando possíveis adulterações e buscando mitigar a possibilidade de falsidades; é ato revogável, porque o declarante pode rever ou desistir das disposições a qualquer momento antes de sua morte, salvo eventual reconhecimento de paternidade, que persistirá ao ato de revogação; e

Mas, mesmo após o advento do Código Civil (de 1916) grande parte da população brasileira continuou se servindo da forma testamentária para manifestação de suas últimas vontades. E, no interior do Brasil (onde vive grande parte da população brasileira), o recurso à forma testamentária ainda é muito utilizado'. Ob. cit., p. 178.

28 WALD, Arnoldo. Direito Civil: direito das sucessões. V. 6. 15. ed., São Paulo: Saraiva, 2012, p. 186.

29 MAXIMILIANO, Carlos, p. 360.

30 Léon Duguit ensina que é ato jurídico todo o ato de vontade interveniente com intenção de produzir uma modificação no ordenamento jurídico tal como existe ou se produziu ou tal que existirá em um momento futuro dado. Os atos jurídicos podem ser lícitos e ilícitos. Estes últimos, em geral, não são praticados com a intenção de produzir efeitos jurídicos; naqueles, há um querer de modificações no mundo jurídico. In: Traité de Droit Constitutionnel. Troisième Édition. Paris: Anicenne Librairie Fontemoing \& C., Éditeurs. 1927, p. 317-354. 
é causa mortis, porque terá eficácia apenas com a morte do testador. ${ }^{31}$

O Código Civil de 2002 estabelece as formas ordinárias ou comuns $\mathrm{e}$ as especiais de testar. As primeiras estão previstas no art. 1.862, incisos I e III, e dizem com a forma pública, a cerrada e a particular. As segundas, encontram-se dispostas nos incisos I a III do art. 1.886 e dispõem sobre o testamento marítimo, o aeronáutico e o militar, proibida a forma híbrida. ${ }^{32}$ A previsão acerca das disposições existenciais encontra regramento no

31 Acerca da eficácia do testamento, já decidiu o TJRS: ANULAÇÃO DE TESTAMENTO. AUSÊNCIA DE VÍCIOS DE CONSENTIMENTO E DE FORMA. 1. O testamento feito com a observância dos requisitos legais é um ato jurídico válido, perfeito e acabado, que ganha eficácia com o óbito, desencadeando os efeitos dele decorrentes. 2. O fato de ter sido ajuizada anterior ação de investigação de paternidade, que foi julgada improcedente, não constitui óbice ao reconhecimento do liame parental entre investigante e investigado através de testamento feito por este. 3. Inexiste afronta à coisa julgada, pois a improcedência da ação investigatória de paternidade não afirma que o réu não era o pai da autora, significando apenas que ela não conseguiu comprovar o liame parental, impedindo apenas a propositura de nova ação. Recurso desprovido. (Apelação Cível No 70026445676, Sétima Câmara Cível, Tribunal de Justiça do RS, Relator: Sérgio Fernando de Vasconcellos Chaves, Julgado em: 18/02/2009).

$32 \mathrm{O}$ testamento público guarda como requisito essencial à sua validade a necessidade que seja escrito por tabelião, em conformidade com as declarações prestadas pelo testador, que poderá valer-se de minuta para tanto, bem como que, após lavrado o instrumento, seja ele lido em voz alta pelo serventuário extrajudicial ao disponente e a duas testemunhas, a um só tempo. Por fim, para conclusão do negócio, vai o instrumento assinado por todos que se fizeram presentes ao ato. É de notar que essa forma testamentária é a única permitida ao cego (art. 1.867), mas é facultada ao surdo, saiba ou não ler (art. 1.866).

A forma cerrada vem prevista nos artigos 1.868 e seguintes do Código Civil, e deverá o testamento ser escrito pelo disponente, ou por outra pessoa, ou pelo tabelião, a seu pedido, sendo que, após assinado pelo testador, será aprovado pelo tabelião, que lavrará e lerá o correspondente auto de aprovação, tudo na presença de duas testemunhas. Ao analfabeto e a quem não possa ler não é permitido testar na forma cerrada (art. 1.872), mas o é ao surdo-mudo, desde que o escreva todo e o assine de sua própria mão (art. 1.873). O testamento hológrafo, particular ou aberto pode ser escrito de próprio punho ou mecanicamente. É o que dispõe o art. 1.876 do Código Civil. No primeiro caso, deve ser lido e assinado por quem o escreveu; no segundo, deve estar a cédula testamentária a salvo de rasuras ou espaços em branco. Em ambos os casos, deve ser lido na presença de no mínimo três testemunhas, que também o subscreverão, sob pena de resultarem inválidas as disposições testamentárias. Dentre os especiais, os testamentos marítimo e aeronáutico podem ser deixados por forma que corresponda ao público ou ao cerrado, e podem ser utilizados por aqueles que estiverem em viagem, a bordo de navio nacional, 
art. 1.857, parágrafo segundo, Código Civil de 2002.

Cada uma dessas formas testamentárias encontra regramento legal específico, requerendo "forma escrita para sua validade, sendo que a sua escrituração pode ser feita em qualquer meio e sobre qualquer material, desde que indelével a grafia", ${ }^{33}$ podendo "ser escrito de próprio punho do testador ou por meios mecânicos", ${ }^{34}$ salvo situação especialíssima, no chamado testamento nuncupativo, permitem-se disposições de viva voz para aqueles que estiverem em combate ou feridos em campo de batalha.

Orlando Gomes esclarece que "na disciplina legal das formas testamen- tárias referem-se apenas os elementos extrínsecos, atinentes ao modo como o testador deve declarar a sua vontade e ao número, rogação e idoneidade das testemunhas instrumentárias. A chamada forma interna, relativa às condições para testar, é objeto de outras disposições". ${ }^{35}$

A capacidade para testar ou capacidade testamentária ativa, vem, pois, regulamentada no art. 1.860 do Código Civil e estabelece que não podem testar os incapazes e os que, no ato de fazê-lo, não tiverem pleno discernimento. Podem testar os maiores de 16 anos, não havendo necessidade de assistência, ${ }^{36}$ especialmente por que se trata de ato personalíssimo.

de guerra ou mercante. O disponente deverá testar perante o comandante, também na presença de duas testemunhas, mas caducará o testamento se o testador não morrer na viagem e, ao seu desembarque em terra, não fizer outro testamento na forma ordinária nos 90 dias subsequentes. Por fim, o testamento militar é possível não apenas aos militares, mas também às pessoas que estejam a serviço das Forças Armadas, quando em campanha, dentro do País ou no exterior, bem como em situação de praça sitiada, ou sem condições de comunicação. Nessa situação, em não havendo tabelião ou seu substituto legal, o testamento deverá ser feito ante duas ou três testemunhas, se o testador não puder ou não souber assinar, caso em que assinará por ele uma delas. Estando tais pessoas em combate, é possível que testem oralmente, confiando sua última vontade a duas testemunhas. Os parágrafos $1^{\circ}$ a $3^{\circ}$ estabelecem situações ainda mais especiais, em que, escrito o testamento, que poderá ser feito de próprio punho pelo testador, desde que assinado por este, deverá ser entregue ao auditor ou oficial de patente que lhe faça as vezes, igualmente na presença de duas testemunhas.

33 GOMES, Orlando. Ob. cit., p. 100.

\section{Ibidem.}

35 GOMES, Orlando. Ob. cit., p. 107.

36 Nesse sentido, TARTUCE, Flávio. Manual de Direito Civil. Volume único. 2. ed. rev. atual. e ampl. Rio de Janeiro: Forense, 2012; São Paulo: Método, 2012, p. 1.311. 
Podem também testar o pródigo, 0 ausente, o silvícola, o falido e o condenado, porque, "quem pode manifestar a sua vontade verbalmente ou por escrito é livre para testar". ${ }^{37}$ Os cegos, os surdos e os mudos podem testar, por que essas condições não lhes retiram a capacidade a tanto, mas apenas limitam as formas testamentárias possíveis de utilização.

A regra é a de que podem testar as pessoas que tiverem pleno discernimento e não a plena capacidade civil, ${ }^{38}$ condição a ser verificada no momento da prática do ato, e não se mede pela situação existente ao tempo da abertura do testamento. ${ }^{39}$

De outro lado, a capacidade de adquirir por testamento ou capacidade testamentária passiva refere-se à faculdade de receber bens deixados por disposição de última vontade na condição de herdeiro ou legatário.

No direito brasileiro toda a pessoa, desde que viva na abertura da sucessão, pode adquirir bens nessa situação. Exceção a essa regra é a prole eventual (ainda não concebidos) de pesso- as certas e determinadas existentes à época de sua morte. ${ }^{40}$ Também podem adquirir por testamento o nascituro e as pessoas jurídicas de direito público interno e de direito privado. Estas, ainda que irregulares, porque indiscutível sua existência, e, ainda que inexistentes na abertura da sucessão, como é o caso das fundações de direito privado, cuja instituição se dá justamente por testamento, consoante disciplina do art. 62 do Código Civil de 2002. ${ }^{41}$

Mas não podem adquirir por testamento as pessoas incertas e indeterminadas, e tampouco as pessoas jurídicas de direito externo, como determina o art. 11 da Lei de Introdução às Normas do Direito Brasileiro. Também não pode ser herdeiro ou legatário a pessoa que escreveu a rogo o testamento, bem como as testemunhas e o intérprete do ato, e ainda aqueles que, em virtude de profissão ou dever de ofício, participem de sua realização ou que tenham recebido as últimas palavras do testador nuncupativo. ${ }^{42}$ Igualmente, a concubina do testador não pode adquirir por testa-

37 WALD, Arnoldo. Ob.cit., p. 160.

38 LEITE, Eduardo de Oliveira. Direito Civil Aplicado. V. 6: Direito das sucessões. São Paulo: Editora Revista dos Tribunais, 2004, p. 187.

39 LEITE, Eduardo de Oliveira. Ob. cit., p. 188.

40 É o que dispõe o art. 1.790, I, do Código Civil de 2002.

41 Nesse sentido, WALD, Arnoldo. Ob. cit., p. 164-176. Nesse particular, o autor distingue incapacidade testamentária (geral ou relativa) e ainda legitimidade para suceder. 42 Nesse sentido, WALD, Arnoldo. Ob. cit., p. 164-176. 
mento na forma do art. 1.801, III, do Código Civil em vigor.

Carlos Maximiliano ${ }^{43}$ ensina que "a vontade individual se prolonga além da morte e até depois de cessar a capacidade jurídica, embora na generalidade dos casos, o direito subjetivo exista ao serviço e no interesse dos vivos". ${ }^{44}$ Esse direito subjetivo do testador ampara-se especialmente no princípio da autonomia privada, sendo o testamento "via adequada para outras manifestações da liberdade pessoal", ${ }^{45}$ como o são as disposições de conteúdo existencial.

Nesse sentido, o Código Civil brasileiro apresenta hipóteses de possíveis disposições testamentárias de conteúdo não patrimonial, como a disposição gratuita do próprio corpo, para depois da morte (art. 14); o reconhecimento de filiação (art. 1.609, III); a nomeação de tutor para os filhos (arts. 1.634, IV, e 1.729, parágrafo único); a revogação de testamento anterior (art. 1.969); a reabilitação do indigno (art. 1.818); a deserdação (art. 1.964); a nomeação de testamenteiro (art. 1.976); sufrágios por alma do falecido (art. 1.998).

Eduardo A. Zannoni, ${ }^{46}$ acerca das disposições extrapatrimoniais, anota que as disposições que podem "contener el testamento no reviesten necessariamente el caráter patrimonial", e completa: "mediante testamento el causante puede limitar-se a reconecer hijos extramatrimoniales, conforme a lo que dispone el art. 248 , inc. $3^{\circ}$. del Cod. Civil", elencando exemplificativamente outras possíveis disposições não patrimoniais: "dar destino a correspondência, condecoraciones, títulos etc., o acerca del cadáver, inhumación, sepultura etcétera [...]". ${ }^{47}$

Tais disposições revelam a íntima vontade do testador, seus sentimentos e sua moralidade, que o fazem formalmente perfilhar. Esse é o aspecto a ser examinado nas próximas linhas.

43 MAXIMILIANO, Carlos. Direito das Sucessões. Rio de Janeiro: Freitas Bastos, 1942, p. 351.

44 Ibidem.

45 TARTUCE, Flávio. Manual de Direito Civil. Volume único. 2. ed. rev. atual. e ampl. - Rio de Janeiro: Forense, 2012; São Paulo: Método, 2012, p. 1.307.

46 ZANONI, Eduardo A. Manual de derecho de las sucessiones. 4. ed. Buenos Aires: Editorial Astrea de Alfredo Y Ricardo Depalma, 1999, p. 544.

47 ZANONI, Eduardo A., Idem. 


\section{RECONHECIMENTO DE FILHOS POR TESTAMENTO}

Dentre os modos de reconhecimento voluntário dos filhos ${ }^{48}$ ou perfilhação previstos no artigo 1.609 do Código Civil de $2002^{49}$ consta o testamentário, ainda que incidentalmente manifestado..$^{50} \mathrm{O}$ testamento pode, pois, ser utilizado para reconhecimento de filho, que poderá preceder ao nascimento do perfilhado, ou seja, do nascituro, ou ser posterior ao seu falecimento (post mortem), se ele deixar descendentes. ${ }^{51}$

Nelson Nery Junior e Rosa Maria de Andrade Nery ${ }^{52}$ anotam que o reconhecimento de filhos por testamento "é hipótese de reconhecimento inci- dentalmente manifestado à ocorrência prevista no CC 1803", que dispõe que "é lícita a deixa ao filho do concubino, quando também o for do testador", pelo que "o filho do testador, nascido de relacionamento concubinário é, como os outros, igualmente filho e herdeiro, podendo ser agraciado por disposições testamentárias e reconhecido por testamento". ${ }^{33}$

Não há necessidade de que o testamento seja realizado para essa finalidade específica, ${ }^{54}$ mas deverá assegurar a efetiva manifestação da vontade do testador, pelo que as diversas modalidades de testamento previstas no ordenamento jurídico brasileiro guardam em comum a forma escrita - salvo o militar, único que admite feitura

48 No ordenamento jurídico brasileiro, o reconhecimento de filhos pode ser dar por duas formas básicas, quais sejam, reconhecimento voluntário ou perfilhação (art. 1.609, do Código Civil brasileiro); ou judicial, quando não houver o reconhecimento voluntário, devendo ocorrer por meio de ação de investigação de paternidade, de modo coativo. Nesse sentido, TARTUCE, Flávio. Ob.cit. p. 1.179.

$49 \mathrm{O}$ reconhecimento de filhos era tratado pela Lei n. 8.560/92.

$50 \mathrm{O}$ art. 1.609 do Código Civil de 2002, arrola as seguintes formas de reconhecimento voluntário de filhos: I - No registro de nascimento; II - Por escritura pública ou escrito particular, a ser arquivado em cartório; III - Por testamento, ainda que incidentalmente manifestado; IV - Por manifestação direta e expressa perante o juiz, ainda que o reconhecimento não haja sido o objeto único e principal do ato que o contém.

51 É o que dispõe o parágrafo único do art. 1.609 do Código Civil de 2002.

52 NERY JUNIOR, Nelson. NERY, Rosa Maria de Andrade. Código Civil Comentado, 8. ed., rev., ampl. e atual. até 12.07.2011. São Paulo : Editora Revista dos Tribunais, 2011, p. 1.193.

53 NERY JUNIOR, Nelson. NERY, Rosa Maria de Andrade. Ob. cit., p. 1.309.

54 Nesse sentido, GONÇALVES, Carlos Roberto. Direito Civil Brasileiro: Direito de Familia. V. 6, 10 ed. São Paulo: Saraiva, 2013. p. 347. 
oral, quando as pessoas referidas no art. 1.893 estiverem feridas ou em combate (art. 1.896, Código Civil) -, e a necessidade de assinatura do testador, ou a seu rogo, como permitem os testamentos público e cerrado (arts. 1.865 e 1.868$).{ }^{55}$

A inobservância de quaisquer dos requisitos legais pode ensejar a nulidade ou a anulabilidade do testamento, aplicando-se a teoria das nulidades pre- vista na parte geral do Código Civil. ${ }^{56}$ Manter-se-á, no entanto, a perfilhação, como escritura pública, se revogado for o testamento público, ${ }^{57}$ resultando também confirmado o caráter da irrevogabilidade, consoante previsão do art. 1.610 do Código Civil.

Isso porque "a irrevogabilidade é corolário do reconhecimento do filho havido fora do casamento". Embora a irrevogabilidade, em se tratando "de

55 A forma pública (art. 1.862, I, Código Civil de 2002) tem como requisito essencial a assinatura do testador, do tabelião e das duas testemunhas, sendo que, se o primeiro não puder ou não souber assinar, uma das testemunhas instrumentárias poderá assinar a seu rogo (art. 1.865), o que será declarado pelo tabelião. Não há exigência, nessa forma de testamento, de a obrigatoriedade das declarações do testador serem prestadas de viva voz, afastando-se o princípio da oralidade adotado pelo Código de 1916, permitindo expressamente a possibilidade de utilização de minutas ou apontamentos pelo disponente. As testemunhas não precisam estar presentes na lavratura do ato, fazendo-se requisito essencial apenas que elas assistam à leitura de todo o testamento, que deverá ser feita a um só tempo. Apostas as assinaturas logo após a leitura, estará perfectibilizado o ato. $\mathrm{O}$ testamento cerrado ou secreto exige a assinatura do testador na própria cédula, enquanto o auto de aprovação deve ser também assinado por este, pelo tabelião e por duas testemunhas (arts. 1.868 e incisos), podendo ser escrito também mecanicamente. Os testamentos marítimo e aeronáutico devem seguir também a forma pública ou a cerrada (art. 1.888), de sorte que podem ser feitos mecanicamente, enquanto o militar também pode ser cerrado (art. 1.894). Exige-se, pois, a assinatura do testador, do tabelião, ou do comandante, ou do auditor, ou de quem lhe faça as vezes, conforme o caso, e das testemunhas, permitindo-se que uma das testemunhas assine a rogo do testador. Ao seu turno, o testamento particular deve ser escrito e assinado de próprio punho pelo testador e por três testemunhas, bem como poderá ser elaborado por processo mecânico, caso que devem ser observadas as mesmas exigências quanto à assinatura do disponente $\mathrm{e}$ das testemunhas, que igualmente deverão assiná-lo. A possibilidade de utilização meio mecânico na feitura das disposições de última vontade é traço comum de todas as formas testamentárias, e bem assim, a aposição de assinatura manuscrita ou a rogo, cedendo apenas em hipótese especialíssima que permite ao testador dizer sua última vontade quando em combate ou ferido, no caso do testamento militar.

56 TARTUCE, Flávio. Ob. cit., p. 1.310.

57 WALD, Arnoldo. Ob. cit., p. 152. 
um testamento cerrado inquinado de vício, só valerá o reconhecimento como início de prova por escrito, ou seja, como fundamento para intentar uma investigação de paternidade". ${ }^{58}$

O testamento, como já referido, é negócio jurídico unilateral "em que o beneficiário não intervém'. ${ }^{59}$ A par disso, o reconhecimento de filho é, a exemplo do testamento, unilateral, em que a necessidade de aceitação do filho maior "é mero ato de proteção, protegendo a iniciativa daquele que reconhece o filho". ${ }^{60} \mathrm{Em}$ sendo menor o perfilhado, poderá ele impugnar o reconhecimento, a contar da maioridade, no prazo decadencial de quatro anos, na forma do art. 1.614 do Código Civil de 2002.

A perfilhação pela via testamentária independe do vínculo biológico entre o testador e o beneficiário dessa disposição, porque poderá ocorrer igualmente e pela mesma via o reconhecimento de paternidade socioafetiva. Mesma sorte, o ato de reconhecimento poderá ocorrer antes do nascimento ou após a morte do perfilhado.

O nascituro é a pessoa por nascer, a qual embora ainda não tenha personalidade, tem seus direitos resguardados pelo ordenamento jurídico brasileiro desde a concepção, tendo o Código Civil assegurado o direito a suceder por sucessão testamentária "os já concebidos no momento da sucessão". ${ }^{61}$

No que refere ao reconhecimento de paternidade testamentária post mortem do perfilhado, ter-se-á uma perfilhação perfectibilizada após a morte do perfilhante e com efeitos também após a morte do perfilhado, assegurando-se todos os direitos existenciais e patrimoniais decorrentes dessa relação jurídica, em especial, nessa singular hipótese, dos direitos sucessórios daí decorrentes.

Em outra situação, parece não haver nenhuma vedação ao reconhecimento de filhos ainda não concebidos à época da abertura da sucessão, no caso do filho consanguíneo, havido por técnica de reprodução assistida homóloga, quando já falecido o marido. Nessa hipótese, o fundamento da filiação é biológico, por presunção legal (art. 1.597, III, in fine, Código Civil de 2002). Acerca do tema, pontuam Nelson Nery Júnior e Rosa Maria de Andrade Nery ${ }^{62}$ :

58 WALD, Arnoldo. Ob. cit., p. 152.

59 WALD, Arnoldo. Ob.cit., p. 154.

60 TARTUCE, Flávio. Ob. cit., p. 1.180.

61 Art. 1.784 do Código Civil.

62 NERY JUNIOR, Nelson. NERY, Rosa Maria de Andrade. Ob. cit., p. 1.179. 
[...] a utilização de material genético do marido após a sua morte depende apenas de autorização que ele tenha deixado em vida, que não se submete a qualquer solenidade. Esse consentimento informal é, por si só, suficiente para que se dê ocasião para a efetiva fecundação. Com ou sem autorização, contudo, essa filiação pode advir e, se isto ocorrer, essa filiação se estabelece, irradiando efeitos para o direito de sucessões. Vale lembrar que o filho póstumo é herdeiro (art. 227, §6), mas a lei não contribui para resolver essa situação (CC 1798).

Assim, sem autorização do marido falecido à época da concepção, a certeza da paternidade, caso contestada, somente ocorrerá pela realização de exame de DNA, na forma do art.1.606 do Código Civil de 2002, ou poderá ser afirmada pelo reconhecimento testamentário a satisfazer a exigência legal da referida autorização.

É certo, ademais, que o reconhecimento de paternidade pela via em análise passa pelo exame dos correspondentes direitos de personalidade do perfilhante e do perfilhado, o que será objeto de análise do tópico a seguir.

\section{DIREITOS DE PERSONALIDADE}

A rigor, os direitos da personalidade são uma conquista da idade moderna, ${ }^{63} \mathrm{e}$ foram paulatinamente reconhecidos, em conformidade com as exigências do indivíduo enquanto pessoa, em processo global ainda em evolução. Acerca dessa evolução, Milton Fernandes ${ }^{64}$ aponta os estudos de Heinrich Hubmann:

[...] no estado tribal primitivo, uma sociedade nômade e pastoril cuidou de assegurar o amparo da pessoa física contra a violência e o roubo. $\mathrm{O}$ advento da agricultura criou uma coletividade sedentária. O campo cultivado fez a casa fixa suceder à tenda. Desponta, assim, a proteção dos bens imóveis. O desenvolvimento do intercâmbio entre povoados acarretou a necessidade de uma identificação individual: o estado civil dota a pessoa de um estatuto social, fixando o nome de família, enquanto se acentua o fenômeno da urbanização.

A comunicação não se limita à vida oral. Pela escrita, vai-se desenvolvendo, paralelamente à alfabetização, a que corresponde à criação do servi-

63 FERNANDES, Milton. Os direitos da personalidade. Estudos Jurídicos em homenagem ao Professor Caio Mario da Silva Pereira. Forense: Rio de Janeiro, 1984, p. 131-159.

64 FERNANDES, Milton. Ob. cit. 
ço postal. A tutela da correspondência estende-se do suporte material ao conteúdo intelectual.

As últimas etapas são as que asseguram o desenvolvimento dos direitos de personalidade, a partir do século XIX.

Superando a Declaração dos Direitos do Homem e do Cidadão de 1789, que tinha como destinatários o homem abstrato, a universalidade das disposições da Declaração de 1948 revela-se um verdadeiro 'sistema de direitos no sentido estrito da palavra, isto é, enquanto direitos positivos ou efetivos', ${ }^{65}$ e também o ponto de partida para a efetividade dos direitos que positiva. ${ }^{66}$

E é nesse sentido que a irrupção da pessoa no mundo do direito veio efetivamente a ocorrer após a Segunda Guerra Mundial, por meio da Declaração Universal dos Direitos do Homem de 1948, ${ }^{67}$ que, de cunho universal, consiste na passagem da teoria à prática, positivando direitos do homem situado, concreto, ímpar em suas necessidades e inserto em um meio social em constante e diferenciada evolução.
O necessário caminho para a efetiva concretização dos direitos do homem passa pela especialização desses direitos, verificados em conformidade com as necessidades específicas de grupos identificados como merecedores de proteção especial, como é o caso dos formados por crianças, adolescentes, mulheres, idosos, deficientes entre outros. Trata-se da proteção dos vulneráveis, dos mais fracos, daqueles com condições existenciais mitigadas pelo meio político, social e econômico onde vivem.

Um segundo trajeto na realização desses direitos consiste essencialmente na adoção das orientações internacionais, perfectibilizadas por meio dos tratados e convenções internacionais de direitos humanos específicos, pelos ordenamentos jurídicos internos dos países partes desses meios de proteção. E essa adoção se fez possível, no direito brasileiro, por meio da Constituição Federal de 1988, que tem como um de seus fundamentos a dignidade da pessoa humana.

A necessidade de proteção dos direitos do homem ${ }^{68}$ conclama, pois, as Constituições a conferir uma uni-

65 BOBBIO, Norberto. A era dos direitos. Tradução Carlos Nelson Coutinho. 11. ed. Rio de Janeiro: Campus, 1992. p. 26.

\section{Ibidem.}

67 BOBBIO, Norberto. A era dos direitos. Tradução Carlos Nelson Coutinho. 11. ed. Rio de Janeiro: Campus, 1992. p.26.

68 Nesse sentido, Norberto Bobbio questiona como fundamentar os direitos do homem, tendo em conta a impossibilidade de dar-lhes uma noção precisa, para concluir que não 
dade de sentido, de valor e de concordância prática ao sistema de direitos fundamentais. ${ }^{69}$ É o que ensina Jorge Miranda $^{70}$ ao afirmar que esse entendimento repousa na dignidade da pessoa humana, ${ }^{71}$ o que faz da pessoa fundamento e fim da sociedade, a par de enfatizar que, para além da unidade do sistema, o que conta é a unidade da pessoa, do "homem situado" no mundo plural, e portanto conflitual, em acelerada mutação.

A dignidade da pessoa humana ${ }^{72}$ para Ingo Wolfgang Sarlet ${ }^{73}$, em uma

se pode propor a busca de um fundamento absoluto desses direitos. Todavia, assevera que problema fundamental em relação aos direitos do homem, hoje, não é tanto o de justificá-los, mas de protegê-los. (Ibid., p. 18-24).

69 Ricardo Antonio Lucas Camargo pontua, nesse particular, que "embora a doutrina insista na distinção entre Direitos Humanos e Direitos Fundamentais, o fato de o Direito Constitucional positivo brasileiro haver insculpido em seu texto direitos catalogados em Tratados Internacionais, como reconhecem Jorge Renato dos Reis, Eduardo Fischer e Max Möller: "fez com que expressões como Direitos Fundamentais e Direitos Humanos fossem tidas por sinônimas". Custos dos direitos e reforma do estado. Porto Alegre: Fabris, 2008. p. 111-112.

70 MIRANDA, Jorge. Manual de direito constitucional. 3. ed. rev. e atual. Coimbra: Coimbra, 2009. V. 4, p. 180-182.

71 Antônio Junqueira de Azevedo refere que "a utilização da expressão 'dignidade da pessoa humana' no mundo do direito é fato histórico recente. Evidentemente, muitas civilizações, graças especialmente a seus heróis e santos, respeitaram a dignidade da pessoa humana, mas juridicamente a tomada de consciência, com a verbalização da Express, foi um passo notável dos tempos mais próximos". A par disso, anota o autor que "parece que a expressão em causa surgiu pela primeira vez, nesse contexto preceptivo em que hoje está sendo usada, em 1945, no 'Preâmbulo' da Carta das Nações Unidas ('dignidade e valor do ser humano'). A palavra 'dignidade', porém utilizada em contexto ético, não jurídico, para o ser humano, já está muito precisamente em Kant, que opõe 'preço' - 'Preis', para tudo que serve de meio à 'dignidade' - 'Würde', para o que é um fim em si mesmo o valor intrínseco do ser racional (para o citado filósofo, somente o homem está nessa condição" (AZEVEDO, Antonio Junqueira. Caraterização jurídica da dignidade da pessoa humana. Revista dos Tribunais, São Paulo, v. 91, n. 797, p. 11-26, mar. 2002).

72 Acerca da caracterização jurídica da dignidade da pessoa humana, Antônio Junqueira de Azevedo anota que esta "como princípio jurídico pressupõe o imperativo categórico da intangibilidade da vida humana e dá origem, em sequência hierárquica, aos seguintes preceitos: 1. respeito à integridade física e psíquica das pessoas; 2. consideração pelos pressupostos materiais mínimos para o exercício da vida; e, 3. respeito às condições mínimas de liberdade e convivência social igualitária”. (Ibid.).

73 SARLET, Ingo Wolfgang. Dignidade da pessoa humana e direitos fundamentais na Constituição Federal de 1988. 7. ed. Porto Alegre: Livraria do Advogado, 2009. p. 67. 
perspectiva muldimensional, aberta e inclusiva, é precisamente "a qualidade intrínseca e distintiva reconhecida em cada ser humano que o faz merecedor do mesmo respeito e da mesma consideração por parte do Estado e da comunidade". E completa: "implicando, neste sentido, um complexo de direitos e deveres fundamentais que assegurem a pessoa tanto contra todo e qualquer ato de cunho degradante $\mathrm{e}$ desumano, como venham a lhe garantir as condições existenciais mínimas para uma vida saudável".

Confere-se, assim, eficácia irradiante $^{74}$ das normas definidoras dos direitos fundamentais a todo ordenamento jurídico, indicando que "a elevação dos fundamentos do direito civil ao status constitucional foi uma deliberada escolha axiológica da sociedade, indispensável para a consolidação do Estado Democrático e Social de Direito e da consequente promoção da justiça social e da solidariedade" ${ }^{75}$ Acerca do tema, pontua Ingo Wolfgang Sarlet: ${ }^{76}$
Como um dos mais importantes desdobramentos da força objetiva dos direitos fundamentais, costuma-se apontar para o que boa parte da doutrinal e jurisprudência constitucional na Alemanha denominou de eficácia irradiante dos direitos fundamentais, no sentido de que estes, na sua condição de direitos objetivos, fornecem impulsos e diretrizes para a aplicação e avaliação do direito infraconstitucional, implicando uma interpretação conforme os direitos fundamentais de todo o ordenamento jurídico.

Assim é que, no direito brasileiro, a dignidade da pessoa humana e sua correspondente esfera de proteção são o "elemento nuclear dos direitos fundamentais", 77 constituindo o "fio condutor" da travessia para o Direito Civil contemporâneo, ${ }^{78}$ porque os direitos fundamentais merecem proteção onde quer que se encontre o indivíduo, seja no âmbito público ou privado.

E, em razão disso é que, no ordenamento jurídico brasileiro há uma

74 SARLET, Ingo Wolfgang. A constituição concretizada: construindo pontes com o público e o privado. Porto Alegre: Livraria do Advogado, 2000a. p. 107-163. 75 LÔBO, op. cit., p. 18-28.

76 SARLET, Ingo Wolfgang. Dos Direitos e Garantias Fundamentais. Comentário ao Título II, Dos Direitos e Garantias Fundamentais. In: CANOTILHO, J. J. Gomes; MENDES, Gilmar F.; SARLET, Ingo W.; STRECK, Lenio L. (Coords.) Comentários à Constituição do Brasil. São Paulo: Saraiva/Almedina, 2013, p. 337-342.

77 FACHIN; RUZYK, 2006.

78 Ibid. 
correlação entre direitos fundamentais e direitos de personalidade, indicando um processo que a doutrina ${ }^{79}$ denominou de constitucionalização do direito civil, ${ }^{80}$ em que diluem-se as esferas públicas e privadas na busca de proteção desses direitos, em que estes não são opostos unicamente ao Estado, mas também aos próprios particulares nas relações privadas travadas entre si.

No ordenamento jurídico brasileiro, pessoa ${ }^{81}$ é o titular de direitos e destinatário de obrigações; é o ser que nasce com vida, momento em que adquire personalidade, a qual é conferida pelo direito às pessoas naturais e, por ficção, às pessoas jurídicas.

No que refere à pessoa humana, Antônio Chaves anota que "personalidade nada mais é do que a reunião dos elementos psíquicos que formam a pessoa, ser diferente dos demais, individualidade com características próprias", ${ }^{82}$ e que coincide, a rigor, com a duração da vida humana: tem início com o nascimento, com vida, e termina com a morte, ${ }^{83}$ que pode ser

79 Ver, por todos, Ibid.

80 Paulo Lôbo ensina que a constitucionalização do direito civil, no Brasil, é um fenômeno doutrinário que tomou corpo principalmente a partir da última década do século $\mathrm{XX}$, entre os juristas preocupados com a revitalização do direito civil e sua adequação aos valores que tinham sido consagrados na Constituição de 1988, como expressões das transformações sociais. Disseminou-se a convicção da insuficiência da codificação, e até mesmo a superação de sua função, ante a complexidade da vida moderna e o advento dos microssistemas jurídicos pruridisciplinares, como o direito do consumidor, o direito ambiental, os direitos da criança e do adolescente e do idoso. (LÔBO, Paulo Luiz Netto. A constitucionalização do direito civil brasileiro. In: TEPEDINO, Gustavo. (Org.) Direito civil contemporâneo: novos problemas à luz da legalidade constitucional. São Paulo: Atlas, 2008, p. 18-28.)

$81 \mathrm{O}$ conceito jurídico de pessoa humana foi recentemente delimitado pelo Supremo Tribunal Federal, ao julgar a Ação de Declaração de Inconstitucionalidade n. 3.510, que teve por objeto o bloco do artigo $5^{\circ}$ da Lei n. 11.105, de 24 de março de 2005, Lei de Biossegurança, em que se questionou a constitucionalidade do uso de células-tronco embrionárias em pesquisas científicas para fins terapêuticos. No caso, a Suprema Corte brasileira entendeu pela constitucionalidade dos dispositivos legais objeto da referida ADI, por entender que, no ordenamento jurídico brasileiro, o ser humano torna-se pessoa a partir do nascimento com vida, embora confira proteção legal ao nascituro desde a concepção.

82 CHAVES, Antônio. Tratado de Direito Civil. V. 1. Parte Geral, Tomo I. São Paulo: Revista dos Tribunais, 1982, p. 186.

83 O Código Civil de 2002 dispõe acerca da legitimação para a proteção dos direitos de personalidade do morto (arts. 12, parágrafo único, e 20, parágrafo único). 
real ou ficta, por presunção, com ou sem declaração de ausência. ${ }^{84}$

A personalidade é definida por particularidades capazes de identificar o indivíduo em seu meio social, como o nome, o estado e o domicílio. Com efeito, "pelo nome, identifica-se a pessoa; pelo estado, a sua posição na sociedade política, na família, como indivíduo; pelo domicílio, o lugar de sua atividade social". ${ }^{85}$ Esses elementos que permitem a perfeita identificação da pessoa e que a individualiza e a diferencia em seu meio social em relação aos demais, denominam-se atributos da personalidade. ${ }^{86}$

Por sua vez, os direitos da personalidade são aqueles "considerados essenciais à pessoa humana, que a doutrina moderna preconiza e disciplina, a fim de resguardar a sua dignidade". ${ }^{87}$ Apontando diversidade de conceitos doutrinários e para bem defini-los, Or- lando Gomes, sugere a delimitação de seu objeto, como "bens jurídicos em que se convertem projeções físicas ou psíquicas da pessoa humana, por determinação legal que os individualiza para lhes dispensar proteção". ${ }^{88}$

Nesse sentido, para o autor "a teoria dos direitos de personalidade somente se liberta de incertezas e imprecisões se a sua construção se apoia no Direito Positivo e reconhece o pluralismo desses direitos ante a diversidade dos bens jurídicos em que recaem, tanto mais quanto são reconhecidamente heterogêneos". ${ }^{89}$ Os direitos de personalidade não são classificáveis entre os direitos pessoais ou reais ${ }^{90}$, mas distinguem-se por serem "absolutos, extrapatrimoniais, intransmissíveis, imprescritíveis, impenhoráveis, vitalícios e necessários", ${ }^{91}$ e "opõem-se erga omnes, implicando o dever geral de abstenção". ${ }^{92}$

84 A morte presumida pode ser declarada sem decretação de ausência, nos casos indicados nos incisos I e II do art. 7 do Código Civil brasileiro, a saber: se for extremamente provável a morte de quem estava em perigo de vida; se alguém, desaparecido em campanha ou feito prisioneiro, não for encontrado até dois anos após o término da guerra. Além disso, a Lei n. 9.140, de 1995, reconhece como mortas as pessoas desaparecidas em razão de participação, ou acusação de participação, em atividades políticas no período de 02.09.1961 a 05.10.1988.

85 GOMES, 1987, p. 129.

86 NERY, Nelson. NERY, Rosa Maria de Andrade. Ob. cit., p. 208.

87 Ibid,. p. 129.

88 Ibid., p. 131.

89 Ibid., p. 132.

90 Ibid., p. 132.

91 Ibid., p. 132.

92 Ibid., p. 132. 
$\mathrm{Na}$ classificação de Orlando Gomes, os direitos à integridade física e à integridade moral formam dois grandes grupos dos direitos de personalidade, arrolando, no primeiro, o direito à vida e direitos sobre o próprio corpo; no segundo, a relação é formada pelo direito à honra, à liberdade, ao recato, à imagem, ao nome e, também, pelo direito moral do autor.

O Código Civil de 2002 dedicou um capítulo aos direitos de personalidade, positivando em seu artigo $11 \mathrm{o}$ caráter intransmissível e irrenunciável desses direitos, bem como estabeleceu regras acerca da disposição do próprio corpo (art. 13), também para além da morte (art. 14), enquanto o Estatuto do Idoso estabeleceu que envelhecer é direito personalíssimo. Não se quer dizer com isso que os direitos de personalidade estejam tipificados na lei, mas, apenas demonstrar que estão positivados em rol exemplificativo a fim de atender à exigência de um direito geral de personalidade,,$^{93}$ porque esta não se restringe à classificação legal.

$\mathrm{O}$ ato de testar pode ser meio de proteção de alguns dos direitos de personalidade do testador, que tem preservada, pela via testamentária, intenções e aspectos de sua vida privada, de sua intimidade, que não deseja revelar ou levar a efeito em vida. O sigilo, especialmente por meio do testamento cerrado, possibilita esse resguardo nos limites impostos pela lei, quer no que se refere às disposições patrimoniais, que são limitadas a metade da herança, caso tenha deixado herdeiros necessários, ${ }^{94}$ quer no que consta em conteúdo existencial, que não poderá contrariar a ordem pública e os bons costumes. ${ }^{95}$

O reconhecimento de filho por testamento propicia essa proteção especialmente no que refere à intimidade e à vida privada do testador. Isso porque a perfilhação poderá estar no plano das questões que o testador deseja que sejam reveladas e que tenham efeitos somente depois de sua morte. Nesse particular, embora público o testamento, e que tenha sido revogado, uma vez verificada a perfilhação, esta somente surtirá efeitos após o decesso do disponente, tendo em conta que não há nenhuma exigência legal de que seja o reconhecimento de pa-

93 SOUZA, Rabindranath Valentino Aleixo Capelo de Souza. O Direito Geral de Personalidade. Dissertação de doutoramento. Coimbra Editora, 1995.

94 Arts. 1.845 e 1846 do Código Civil de 2002.

95 NERY JUNIOR, Nelson. NERY, Rosa Maria de Andrade. Código Civil Comentado, 8. ed., rev., ampl. e atual. até 12.07.2011. São Paulo: Editora Revista dos Tribunais, 2011, p. 1.336 . 
ternidade registrado no momento da revogação.

Para além disso, o reconhecimento de paternidade pela via testamentária está intrinsecamente relacionado aos atributos da personalidade do reconhecido, como a determinação do nome, do estado familiar e sucessório, constituindo-se em título do estado de família, para fins de registro, ${ }^{96}$ conferindo ao perfilhado o caráter de sujeito do conjunto de direitos e deveres decorrentes desse estado familiar, ${ }^{97}$ que também é atributo da personalidade.

O nome revela o tronco familiar a que pertence a pessoa, ao tempo em que singulariza o sujeito que identifica, simbolizando o direito à identidade; enquanto o estado de família indica a posição familiar da pessoa, da qual decorrem direitos e deveres correlatos. ${ }^{98}$

Ocorrendo a perfilhação perfectibiliza-se o direito à filiação, cuja proteção decorre de mandamento constitucional, tal como preconiza o parágrafo $6^{\circ}$ do art. 227 da Constituição Federal, que dispõe que "os filhos, havidos ou não da relação do casamento, ou por adoção, terão os mesmos direitos e as mesmas qualificações, proibidas quaisquer designações discriminatórias relativas à filiação".

O Estatuto da Criança e do Adolescente, por sua vez, reproduz a norma constitucional e prevê expressamente que "o reconhecimento do estado de filiação é direito personalíssimo, indisponível e imprescritível, podendo ser exercitado contra os pais ou seus herdeiros, sem qualquer restrição, observado o segredo de Justiça" (art. 27), além de facultar igualmente o reconhecimento de paternidade por testamento (art. 26).

Com efeito, é inequívoco que o direito à filiação é direito de personalidade, porque envolve o conhecimento da identidade biológica ou socioafetiva do perfilhado, e, bem assim o nome, os direitos de família e de sucessão, também previstos constitucionalmente.

Por fim, o reconhecimento de paternidade pela via testamentária, depende da ausência de registro de paternidade na certidão de nascimento do perfilhado, bem como do consenti-

96 NERY JUNIOR, Nelson. NERY, Rosa Maria de Andrade. Acerca do tema, ensinam os autores que "em regra, o título de estado de família consubstancia-se em instrumentos e documentos inscritos no Registro Civil. Contudo, as sentenças judiciais também podem ser constitutivas de um estado de família”. Ob. cit., p. 209.

97 NERY JUNIOR, Nelson. NERY, Rosa Maria de Andrade. Ob.cit., p. 209.

98 Nesse sentido, NERY JUNIOR, Nelson. NERY, Rosa Maria de Andrade. Ob.cit., p. 208-209. 
mento deste. O que implica reconhecer que, nessa situação, essa forma de reconhecimento de paternidade compõe a identidade do reconhecido, reconstruindo sua personalidade.

\section{CONSIDERAÇÕES FINAIS}

A filiação é a relação jurídica entre ascendentes e descendentes de primeiro grau, ou seja, entre pais e filhos, biológicos ou socioafetivos, que determina o nome, o estado de família e sucessório das partes, envolvendo, pois, os correspondentes direitos de personalidade.

Por sua vez, o reconhecimento de paternidade pela via testamentária é direito de personalidade do disponente que diz com sua autonomia pessoal, privacidade e liberdade. $\mathrm{O}$ ato jurídico de testar, nesse plano, produz efeitos no mundo jurídico, modificando atributos da personalidade do perfilhado, que até então não tinha perfectibilizado o seu direito à filiação. Ambas as esferas de direitos de personalidade do perfilhante e perfilhado - guardam intrínseca relação.

Por fim, pode-se afirmar, ademais, que a perfilhação pos mortem pode implicar "abandono em vida" e "amparo após a morte", em que os princípios da solidariedade familiar e da paternidade responsável e os deveres daí decorrentes ficam diferidos para depois do decesso do disponente.

\section{REFERÊNCIAS}

AZEVEDO, Álvaro Villaça. Estatuto da Família de Fato. São Paulo: Editora Atlas S.A., 2002.

BRANDELLI, Leonardo. Teoria do Geral do Direito Notarial, São Paulo: Saraiva, 2007.

CALMON, Petrônio. Comentários à Lei de Informatização do Processo Judicial. Rio de Janeiro: Forense, 2007.

COULANGES, Fulstel de. São Paulo: Martins Fontes, 2000.

DUGUIT, Léon. Traité de Droit Constitutionnel. Troisième Édition.
Paris: Anicenne Librairie Fontemoing \& C., Éditeurs. 1927, p. 317-354.

DINIZ, Maria Helena. Curso de direito civil brasileiro. V. 6: Direito das sucessões. 21. ed., rev. e atual. de acordo com a Reforma do CPC. São Paulo: Saraiva, 2007. . Dicionário jurídico. São Paulo: Saraiva, 1998.

GAGLIANO, Pablo Stolze, Rodolfo Pamplona Filho. Novo curso de direito civil. São Paulo: Saraiva, 2004. 
GILISSEN, John. Introdução Histórica do Direito. Tradução de A. M. Hespanha e L.M. Macaísta Malheiros. 2. ed. Lisboa: Fundação Calouste Gulbenkian, 1995.

GONÇALVES, Carlos Roberto. Direito Civil Brasileiro. V. 6: Direito de Família. 10. ed. São Paulo: Saraiva, 2013.

FERREIRA, Aurélio Buarque de Holanda. Novo Aurélio Século XXI: $\mathrm{O}$ dicionário da língua portuguesa / Aurélio Buarque de Holanda Ferreira. 3. ed. rev. e ampl. Rio de Janeiro: Nova Fronteira, 1999.

GOMES, Orlando. Sucessões. 14. ed., rev., atual. e aumentada de acordo com o Código Civil de 2002, por Mario Roberto Carvalho de Faria. Rio de Janeiro: Forense, 2008.

LEITE, Eduardo de Oliveira. Direito Civil Aplicado. V. 6: Direito das sucessões. São Paulo: Editora Revista dos Tribunais, 2004.

MARQUES, Claudia Lima et al. Comentário ao Código de Defesa do Consumidor. São Paulo: Revista dos Tribunais, 2006.

MARTINS-COSTA, Judith. Comentário ao art. 5., inciso XXX. In: CANOTILHO, J. J. Gomes; MENDES, Gilmar F; SARLET, Ingo W.; STRECK, Lenio L. (Coords.) p. 337-342. Comentários à Constituição do Brasil. São Paulo: Saraiva/Almedina, 2013.

MAXIMILIANO, Carlos. Direito das Sucessões. Rio de Janeiro: Freitas Bastos, 1942.
MENKE, Fabiano. Assinatura Eletrônica no Direito Brasileiro. São Paulo: Revista dos Tribunais, 2005

NADER, Paulo. Direito da Sucessões, V. 6. 2. ed. Rio de Janeiro: Forense, 2008.

OLIVEIRA, Euclides de. Direito de Herança. A nova ordem da sucessão. São Paulo: Saraiva, 2005.

OLIVEIRA, Itabaiana. Tratado de Direito das Sucessões. São Paulo: Brasil, 1952.

PINHEIRO, Patrícia Peck. Direito digital. 2. ed. São Paulo: Saraiva, 2007.

RÉGIS. Mário Luiz Delgado. Controvérsias na Sucessão do Cônjuge e do Convivente. Será que Precisamos Mudar o Código Civil? Revista Brasileira de Direito de Família. Porto Alegre: Síntese, IBDFAM. Ano 7. n. 29, p. 191222, abr./maio, 2005.

RIZZARDO, Arnaldo. Direito das Sucessões. 4. ed. Rio de Janeiro: Forense, 2008.

SANSEVERINO, Francisco de Assis. Direito Eleitoral. Porto Alegre, 2008.

SANTOLIM, Cesar. Aspectos jurídicos do governo eletrônico: as tecnologias da informação na Administração Pública. Revista de Direito de Informática e Telecomunicações (RDIT), Belo Horizonte, ano 2, n. 2, p. 85-97, jan./ jun. 2007. 
SANTOS, Luiz Felipe Brasil. Direito das Sucessões - Propostas de Alteração. Revista Brasileira de Direito de Família. Porto Alegre: Síntese, IBDFAM. Ano 7. n. 29, p. 185-190, abr./maio, 2005.

SARLET, Ingo Wolfgang. Dos Direitos e Garantias Fundamentais. Comentário ao Título II, Dos Direitos e Garantias Fundamentais. In: CANOTILHO, J. J. Gomes; MENDES, Gilmar F.; SARLET, Ingo W.; STRECK, Lenio L. (Coords.) Comentários à Constituição do Brasil. p. 337-342. São Paulo: Saraiva/Almedina, 2013.

SARLET, Ingo Wolfgang. Dignidade da pessoa humana e direitos fundamentais na Constituição Federal de 1988. 7. ed. Porto Alegre: Livraria do Advogado, 2009.

SICA, Salvatore. SATANZIONE, Pasquale. Commercio elettronico e categorie civilistiche. Milano: Guiffrè Editore. 2002.

SILVA, Clóvis Veríssimo do Couto e. O Direito Privado brasileiro na visão de Clóvis do Couto e Silva. Vera Maria Jacob de Fradera (Org.). Porto Alegre Livraria do Advogado, 1997.

SILVA, de Plácido e. Vocabulário Jurídico. 7. ed. Rio de Janeiro: Forense, 1982.

SILVEIRA, Sérgio Amadeu da. Exclusão Digital: A miséria na era da informação. São Paulo: Editora Perseu Abramo, 2005.

SWENSSON, Walter Cruz (et al.). Leis de Registros Públicos Anotada. São Paulo: Editora Juarez de Oliveira, 2003.

TARTUCE, Flávio. Manual de Direito Civil. Volume único. 2. ed., rev., atual. e ampl. Rio de Janeiro: Forense, 2012; São Paulo: Método, 2012.

TORRE, Massimiliano Della. Diritto e Informatica. Milano: Dott. A. Gurffrè Editore, 2007.

ZANONI, Eduardo A. Manuel. De derecho de las sucessiones. 4. ed. Buenos Aires: Editorial Astrea de Alfredo Y Ricardo Depalma, 1999. 